\title{
Persepsi Nelayan Terhadap Status Konservasi Hiu dan Pengaruhnya Terhadap Penangkapan Hiu: Studi Kasus di Kabupaten Badung, Provinsi Bali
}

\author{
Eriq Imanuel a*, I Gede Hendrawan a, Ni Luh Putu Ria Puspitha a \\ a Program Studi Ilmu Kelautan, Fakultas Kelautan dan Perikanan, Universitas Udayana, Kampus UNUD Bukit Jimbaran, Bali 80361, Indonesia \\ * Penulis koresponden. Tel.: 085338457728 \\ Alamat e-mail: eriqimanuel@gmail.com
}

Diterima (received) 7 Agustus 2017; disetujui (accepted) 2 November 2017; tersedia secara online (available online) 4 November 2017

\begin{abstract}
Shark is one of top predator that can define and control marine food chain. Shark breeding process is relatively slow and increase of catching activity has even given worse impact to shark population. Several endangered shark species has already protected the catch activity was banned. Some of them, such as Alopias superciliosus are found in Benoa and Kedonganan harbour. This condition happened because of not enough information and knowledge transfer to the local community about the protected species and catching regulation. Based on that information,the research about fishermen perception on shark conservation status and its correlation with the shark catch is important to be conducted. Data was collected using quisioner through interview approach. All the respondent is men with the age ranged from 16-67 years old, and $98 \%$ of respondent is labor. About $55 \%$ of the respondent graduated from elementary school. The result showed that the fisherman perception of shark conservation status categorized as good, while shark catch that is related with conservation in Badung district is categorized very good. The correlation of fisherman perception to shark conservation status with shark catching effort is negative, and significant to the shark catching effort $(\alpha=0,05)$ in Badung district. It means that if the fisherman perception to the shark conservation status in Badung district increased, so that the catch effort will be decrease.
\end{abstract}

Keywords: shark; shark catch, fisherman perception.

\begin{abstract}
Abstrak
Hiu merupakan predator teratas dalam rantai makanan yang dapat menentukan dan mengontrol jaring-jaring makanan yang sangat komplek. Proses perkembangan ikan hiu yang relatif lambat dan peningkatan aktifitas penangkapan ikan hiu memiliki dampak negatif terhadap populasi ikan hiu. Beberapa jenis hiu yang mengalami ancaman kepunahan telah dilindungi dan dilarang tangkap. Spesies hiu yang dilarang tangkap seperti Alopias superciliosus ditemukan di pelabuhan Kedonganan dan Benoa. Hal ini diduga karena kurangnya informasi dan pengetahuan masyarakat terkait larangan penangkapan beberapa jenis hiu yang terancam dan dilindungi. Oleh karena itu penelitian mengenai persepsi nelayan terhadap status konservasi hiu dan hubungannya dengan penangkapan hiu perlu dilakukan. Data yang digunakan dalam penelitian ini adalah data primer yang diperoleh dari metode kuesioner dengan pendekatan wawancara. Berdasarkan hasil penelitian menunjukkan bahwa profesi nelayan di Kabupaten Badung digeluti oleh kaum laki-laki dengan umur berkisarantara $16-67$ Tahun. Sebanyak 98\% responden termasuk dalam kategoori tenaga kerja, artinya nelayan dianggap dapat bekerja dan mampu bekerja untuk memenuhi kebutuhannya. Tingkat pendidikan responden dominan tamat sekolah dasar sebesar 55\%. Persepsi nelayan terhadap status konservasi hiu di kabupaten Badung tergolong dalam kualifikasi baik, sedangkan penangkapan hiu berhubungan dengan konservasi di kabupaten Badung yang tergolong dalam kualifikasi sangat baik. Persepsi nelayan terhadap status konservasi hiu berpengaruh negatif dan signifikan terhadap usaha penangkapan hiu $(\alpha=0,05)$ di kabupaten Badung, hal ini berarti ketika persepsi nelayan terhadap status konservasi hiu di kabupaten Badung meningkat maka penangkapan hiu di kabupaten Badung akan menurun.
\end{abstract}

Kata Kunci: hiu; penangkapan hiu; persepsi nelayan 


\section{Pendahuluan}

Perairan Indonesia merupakan perairan beriklim tropis yang memiliki tingkat keanekaragaman jenis biota - biota laut tinggi, salah satunya adalah ikan hiu dan tercatat sebagai negara terbesar penghasil ikan hiu (Sembiring et al., 2015). Ikan hiu merupakan salah satu kelompok dari sub kelas ikan bertukang rawan (elasmobranchii) yang hidup pada perairan dangkal hingga palung laut terdalam dan pada daerah beriklim dingin hingga beriklim tropis hangat (Rahmat, 2011). Ikan hiu merupakan salah satu sumber daya alami yang memiliki nilai ekonomis yang cukup tinggi dan merupakan salah satu kegiatan usaha yang bersifat komersial (Suryagalih, 2016). Perdagangan produk hiu secara global diperkirakan sebesar 1.145.087 ton/tahun dan sebagian besar produk tersebut diekspor dalam bentuk sirip, minyak, dan kulit (Suryagalih, 2016; Jabado et al., 2015).

Berdasarkan data statistik perikanan tangkap di Indonesia tahun 2012 menyatakan bahwa penangkapan hiu di Indonesia dari tahun 2005 hingga 2011 adalah berkisar antara 43.306 ton/tahun - 57.462 ton/tahun. Aktifitas perdagangan hiu di Indonesia sudah mendapat perhatian dan sorotan internasional dimana hal itu diakibatkan oleh tingginya angka penangkapan ikan hiu (Saraswati et al., 2016; Handayani et al., 2018). Berdasarkan Internasional Union for the Conservation of Nature (IUCN) dari 1044 jenis hiu dan pari di temukan bahwa 30\% dari jenis hiu dan pari adalah terancam atau hampir terancam punah. Sebanyak $47 \%$ lagi dikategorikan sebagai Data Deficient, artinya lebih banyak informasi diperlukan untuk menempatkannya dalam kategori ancaman. Spesies dalam kategori Data Deficient dapat ditemukan Terancam begitu mereka telah dinilai.

Hiu merupakan top predator dalam rantai makanan sehingga hiu dapat menentukan dan mengontrol jaring-jaring makanan yang sangat komplek (Ferdiansyah dan Hidayat, 2017). Akan tetapi pada umumnya hiu berkembang sangat lambat, dimana hiu memerlukan waktu bertahuntahun untuk mencapai usia dewasa (Worm et al., 2013). Sebagian besar ikan hiu membutuhkan waktu enam sampai delapan belas tahun atau lebih untuk mencapai dewasa (Worm et al., 2013). Mengingat lambatnya proses perkembangan ikan hiu, maka peningkatan aktifitas penangkapan ikan hiu memiliki dampak negative terhadap populasi ikan hiu.

Beberapa jenis hiu yang diperkirakan mengalami ancaman kepunahan masuk dalam Appendiks II CITES (Convention on International Trade in Endanger Species of Wild Fauna and Flora) diantaranya Carcharhinus obscurus, Carcharhinus falciformes, Carcharhinus plumbeus, Carcharhinus longimanus, Sphyrna leweni, Sphyrna zygaena, sphyrna mokarran. Permen KP nomor 12 tahun 2012 mengeluarkan larangan penangkapan spesies hiu Alopias pelagicus, Alopias superciliosus dan Alopias vulpinus, dimana dua spesies diantaranya yaitu Alopias superciliosus dan Alopias pelagicus terdapat di Indonesia.

Pelabuhan Kedonganan merupakan salah satu kawasan pendaratan ikan hiu oleh nelayan di Bali. Hal ini dikarenakan perairan Badung merupakan perairan yang berbatasan langsung dengan samudera Hindia. Hasil tangkapan hiu merupakan jenis tangkapan sampingan (bycatch) dan tangkapan yang tidak diinginkan karena alasan peraturan (Permen KP nomor 12 tahun 2012) dan nilai ekonomi yang kemudian dibuang kembali ke laut (discard) dari tangkapan rawai tuna di Samudera Hindia, dimana hasil tangkapan sampingan (bycatch) hiu selama 2005-2013 adalah sebesar 2.255 ton (15\%) dan discardnya sebesar 30 ton $(0,17 \%)$ (Setyadji et al., 2014).

Hendra et al., (2016) menyatakan bahwa telah ditemukan 23 jenis spesies hiu di pelabuhan Kedonganan dan 3 jenis hiu di pelabuhan Benoa. Diantara spesies yang ditemukan spesies yang masuk dalam apendiks II yaitu spesies Sphyrna leweni dan Alopias superciliosus. Hal ini diduga karena kurangnya informasi dan pengetahuan masyarakat terkait larangan penangkapan beberapa jenis hiu yang terancam dan dilindungi. Simpfendorfer et al., (2011) menyatakan bahwa ketidaktahuan masyarakat tentang jenis hiu yang dilindungi dan terancam akan menyebabkan masalah bagi pengelolaan perikanan dan konservasi hiu.

Pengelolaan perikanan dan konservasi hiu hingga saat ini belum dilaksanakan secara optimal, dimana data dan informasi sosial ekonomi perikanan hiu masih sangat terbatas (Bangun dan Pahlawan, 2014). Informasi mengenai sosial ekonomi perikanan hiu sangat berguna untuk melakukan evaluasi perdagangan spesies, masukan strategi pengelolaan, dan berfungsi 
untuk pengelolaan perikanan hiu dan konservasi hiu (Simpfendorfer et al., 2011). Informasi mengenai persepsi masyarakat terkait status konservasi hiu di kabupaten Badung masih sangat minim. Oleh karena, itu penelitian ini penting dilakukan mengingat tingginya aktifitas penangkapan ikan hiu dan kurangnya informasi mengenai persepsi masyarakat terkait status konservasi hiu.

\section{Metode Penelitian}

\subsection{Waktu dan Tempat}

Waktu pengambilan data dilakukan pada bulan Maret 2017 hingga Mei 2017. Wilayah daerah penelitian yaitu meliputi wilayah pesisir kabupaten Badung (Gambar 1). Wilayah pesisir kabupaten Badung yang dimaksudkan meliputi pesisir Pantai Berawa, Pantai Mengening, Pantai Kedonganan, Pantai Jimbaran, Tanjung Benoa, dan Pantai Samuh. Metode yang digunakan untuk penentuan titik lokasi penelitian adalah purposive random sampling. Purposive random sampling adalah teknik pengambilan data dengan pertimbangan tertentu yaitu untuk mewakili seluruh masyarakat nelayan di kabupaten Badung (Sugiyono, 2016).
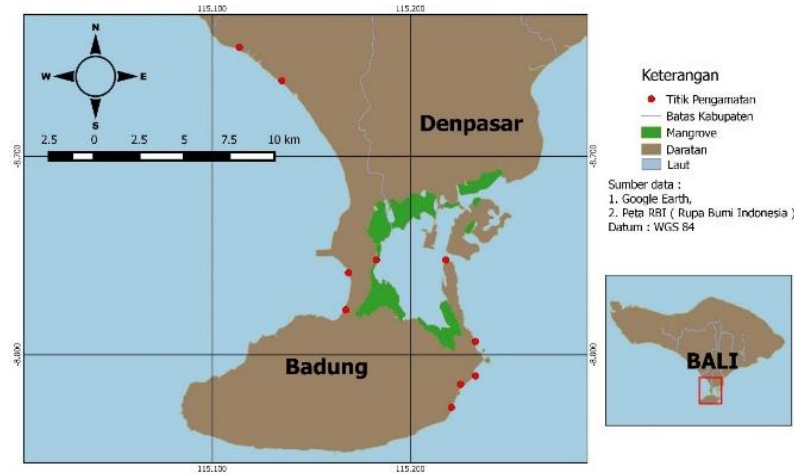

Gambar 1. Lokasi Penelitian

\subsection{Metode Pengambilan Data}

\subsubsection{Sumber Data}

Data yang digunakan dalam penelitian ini adalah data primer. Data primer meliputi data kuesioner dan wawancara. Sasaran dari wawancara adalah nelayan yang terdapat di kabupaten Badung. Nelayan yang dimaksud adalah orang yang mata pencahariannya melakukan penangkapan ikan di laut (Retnowati, 2011). Data sampel yang diambil merupakan bagian dari populasi yang bersifat homogen, artinya memiliki unsur sifat yang sama sehingga tidak dipersoalkan jumlahnya secara kuantitatif, dimana minimal sampel yang diambil adalah sebanyak $1 \%$ dari populasi masyarakat nelayan di kabupaten Badung (Sugiyono, 2016). Dalam penelitian ini, saya mengumpulkan data sebanyak 200 orang nelayan atau setara dengan \pm $9 \%$ dari total populasi nelayan yang ada di kabupaten Badung.

\subsubsection{Teknik Pengumpulan data}

Proses pengambilan data ini dilakukan dengan metode survey. Jansen (2010) menyatakan bahwa metode penelitian survey adalah metode yang dilakukan sebagai kategori umum penelitian yang menggunakan kuesioner dengan pendekatan wawancara. Wawancara yang dilakukan terkait dengan pemahama nelayan terhadap perlindungan hiu dan penangkapan hiu.

Pemahaman nelayan terhadap perlindungan hiu adalah bagian terpenting dari konservasi hiu. Hal ini karena nelayan merupakan komponen yang terlibat langsung dengan kegiatan konservasi hiu, dimana ketika minimnya pengetahuan nelayan terkait perlindungan hiu maka akan berdampak pada pengurangan populasi hiu hingga kepunahan spesies hiu. Pemahaman nelayan disini terkait dengan pengetahuan jenisjenis hiu secara umum, pengetahuan jenis hiu yang dilindungi dan peraturan terkait kegiatan perlindungan hiu.

Pada penelitian ini kuesioner diberikan kepada nelayan dengan metode random sampling sederhana. Metode random sampling sederhana adalah metode pengambilan sampel dimana objekobjek yang akan dijadikan sampel diambil secara acak dan tidak memperhatikan strata (tingkatan) yang ada di populasi (Sugiyono, 2016).

\subsection{Analisis Data}

\subsubsection{Teknik Analisis}

Analisis data kuesioner dilakukan dengan metode analisis statistik deskriptif dan penetapan kriteria penskoran dengan menggunakan skala likert. Boone dan Boone (2012) menyatakan bahwa skala pengukuran adalah kesepakatan yang dipakai menjadi acuan dalam menentukan panjang dan pendeknya interval yang ada dalam alat ukur tersebut sehingga menghasilkan data kuantitatif. Pemberian bobot skala likert dapat dilihat pada Tabel 1. 
Tabel 1

Skala Likert

\begin{tabular}{cc}
\hline ALTERNATIF JAWABAN & BOBOT \\
\hline A & 3 \\
B & 2 \\
C & 1 \\
D & 0 \\
\hline
\end{tabular}

Pada penelitian ini akan dilakukan analisis persepsi masyarakat terhadap konservasi hiu dan hubungannya terhadap penangkapan hiu. Kemudian dilakukan pengelompokan nilai skor tersebut menjadi dua kelompok yaitu kelompok nilai hasil kuesioner persepsi nelayan terhadap status konservasi hiu, sebagai variable bebas $(X)$, dan kelompok nilai hasil kuesioner penangkapan hiu sebagai variabel terikat $(\mathrm{Y})$. Nilai kuantitatif persepsi nelayan terhadap status konservasi dan penangkapan hiu diketahui dengan cara menjumlahkan skor jawaban kuesioner dari setiap responden.

Persepsi nelayan terhadap status konservasi hiu dan penangkapan hiu diketahui dengan menggunakan angka indeks dan analisis jenjang interval (Fachry dan Pertamasari, 2011). Analisis ini bertujuan untuk membuat interval nilai variabel dalam penelitian ini untuk menentukan kriteria sangat baik, baik, cukup baik, kurang baik. Rumus angka indeks ditampilkan pada persamaan 1.

$$
P i=\frac{\sum N i}{\sum N i M a x}
$$

dimana :

$\mathrm{P}_{i}=$ angka indeks, $\mathrm{N}_{\mathrm{i}}=$ Skor pertanyaan ke- $i$. NiMax $=$ Skor maksimum pada setiap pertanyaann ke-i.

Langkah - langkah untuk menghitung angka indeks adalah sebagai berikut :

1. Menentukan jumlah kriteria pertanyaan, jumlah nelayan, dan jumlah pertanyaan. Dalam penelitian ini, jumlah kriteria pertanyaan sebanyak 4 kriteria, skor tertinggi adalah 3 , skor terendah adalah 0 . Jumlah pertanyaan untuk persepsi nelayan terhadap status konservasi hiu adalah 12, sedangkan pertanyaan untuk melakukan penilaian terhadap usaha penangkapan hiu adalah 11.
2. Mencari nilai tertinggi yang diharapkan dari kuesioner ke- $i$

a. Persepsi nelayan terhadap status konservasi hiu :

$\operatorname{NiMax}_{x}=P_{x} \times K_{x} \times n_{x}$

dimana, $P_{x}=$ Jumlah pertanyaan persepsi nelayan terhadap status konservasi hiu, $\mathrm{k}_{\mathrm{x}}=$ kriteria pertanyaan nilai tertinggi, $\mathrm{n}_{\mathrm{x}}=$ jumlah responden

b. Penangkapan Hiu :

$$
\operatorname{NiMax}_{y}=P_{y} \times K_{y} \times n_{y}
$$

dimana, $\mathrm{P}_{\mathrm{y}}=$ Jumlah pertanyaan penangkapan hiu, $\mathrm{k}_{\mathrm{y}}=$ kriteria pertanyaan nilai tertinggi $\mathrm{n}_{\mathrm{y}}=$ jumlah responden)

Rumus nilai jenjang interval ditampilkan pada persamaan (4) .

$N J I=\frac{N \max -N \min }{n}$

Dimana: NJI = Nilai Jenjang Interval, Nmax=angka indeks tertinggi, Nmin = angka indeks terendah, $\mathrm{n}=$ jumlah kriteria pertanyaan

Angka indeks tertinggi $=1$, angka indeks terendah $=0$, jumlah kriteria pertanyaan $=4$.

Sehingga diperoleh kriteria interval variabel $i$ seperti pada Tabel 2.

Tabel 2

Kriteria interval persepsi nelayan terhadap status konservasi hiu

\begin{tabular}{cc}
\hline Interval & Kriteria \\
\hline $0 \geq \mathrm{P}_{i}<0,25$ & Kurang Baik \\
$0,25 \geq \mathrm{P}_{i}<0,50$ & Cukup Baik \\
$0,50 \geq \mathrm{P}_{i}<0,75$ & Baik \\
$0,75 \geq \mathrm{P}_{i} \leq 1$ & Sangat Baik \\
\hline
\end{tabular}

Tabel 3

Kriteria Penangkapan Hiu berhubungan dengan Konservasi Hiu

\begin{tabular}{cc}
\hline Interval & Kriteria \\
\hline $0 \geq \mathrm{P}_{i}<0,25$ & Sangat Baik \\
$0,25 \geq \mathrm{P}_{i}<0,50$ & Baik \\
$0,50 \geq \mathrm{P}_{i}<0,75$ & Cukup Baik \\
$0,75 \geq \mathrm{P}_{i} \leq 1$ & Kurang Baik \\
\hline
\end{tabular}

Pengujian hipotesis dalam penelitian ini adalah melakukan penelaahan yang mendalam terhadap 
berbagai sumber tentang persepsi nelayan terhadap status konservasi hiu dan pengaruhnya terhadap penangkapan hiu di kabupaten Badung. Pengujian hipotesis menggunakan rumus Statistik Regresi Linier Sederhana. Analisis linear sederhana adalah regresi yang menggunakan data yang merupakan hubungan pengaruh antara Variabel X terhadap Variabel Y. Persamaan dasar linier sederhana ditampilkan pada persamaan 5 .

$$
Y=a+b\left(X^{\prime}\right)
$$

dimana

$\mathrm{Y}=$ Penangkapan Hiu

$X=$ Persepsi nelayan terhadap status konservasi hiu

$\mathrm{a}=$ Harga $\mathrm{Y}$ ketika harga $\mathrm{X}=0$ (harga konstan).

$\mathrm{b}$ = Angka arah atau koefisien regresi, yang menunjukkan angka peningkatan ataupun penurunan variabel terikat(dependen) yang didasarkan pada perubahan variabel independen. Bila (+) garis naik, dan bila (-) maka arah garis menurun.

Langkah - langkah uji statistik regresi linier adalah sebagai berikut :

\section{Mencari harga a}

$$
N J I=\frac{\left(\sum Y\right)\left(\sum X^{2}\right)-\left(\sum X\right)\left(\sum X Y\right)}{n \sum X^{2}-\left(\sum X\right)^{2}}
$$

2. Mencari harga $b$

$$
b=\frac{n \sum X Y-\left(\sum X\right)\left(\sum Y\right)}{n \sum X^{2}-\left(\sum X\right)^{2}}
$$

3. Mencari nilai korelasi (r)

$$
r=\frac{n \sum X Y-\left(\sum X\right)\left(\sum Y\right)}{\sqrt{\left.\left(n \sum X^{2}-\left(\sum X\right)^{2}\right) \ln \left(\sum X\right) Y^{2}\right)-\left(\sum Y^{2}-\left(\sum Y\right)^{2}\right.}}
$$

\section{Tabel 4}

Interpretasi terhadap Koefisien Korelasi (Sugiyono, 2016)

\begin{tabular}{cc}
\hline Interval & Tingkat Hubungan \\
\hline $0,00-0,199$ & Sangat rendah \\
$0,20-0,399$ & Rendah \\
$0,40-0,599$ & Sedang \\
$0,60-0,799$ & Kuat \\
$0,80-1,000$ & Sangat Kuat \\
\hline
\end{tabular}

4. Mencari nilai determinasi

$r^{2}=(r)^{2}$

\subsubsection{Uji Statistik (Uji Signifikansi Parsial / Uji t)}

Uji $\mathrm{t}$ merupakan statistik parametris yang digunakan untuk menguji hipotesis komparatif rata - rata dua sampel bila datanya berbentuk interval atau ratio. Pengujian hipotesis menggunakan uji dua pihak, sehingga berlaku ketentuan yaitu jika harga thitung berada pada daerah penerimaan $\mathrm{H}_{0}$ atau terletak di antara harga ttabel, maka $\mathrm{H}_{0}$ diterima dan $\mathrm{H}_{1}$ ditolak. Dengan demikian bila harga thitung lebih kecil atau sama dengan $(\leq)$ dari harga tabel maka $\mathrm{H}_{0}$ diterima. Harga thitung adalah harga mutlak, jadi tidak dilihat (+) atau (-) nya (Sugiyono, 2016). Rumus uji t ditampilkan pada persamaan 10 .

$$
t=\frac{\bar{X}-\bar{Y}}{\sqrt{\frac{S x^{2}}{n x}+\frac{S y^{2}}{n y}-2 r\left(\frac{S x}{\sqrt{n x}}\right)\left(\frac{S y}{\sqrt{n x}}\right)\left(\frac{S y}{\sqrt{n y}}\right)}}
$$

dimana :

$\bar{X} \quad=$ Rata - rata variabel $\mathrm{X}$

$\bar{Y} \quad=$ Rata - rata variabel $Y$

Sx = Simpangan baku variabel $X$

Sy = Simpangan baku variabel $Y$

$S x^{2}=$ Varians variabel $X$

Sy $^{2}=$ Varians variabel $\mathrm{Y}$

$\mathrm{r} \quad=$ korelasi antara 2 sampel

Adapun hipotesis tentang persepsi nelayan terhadap status konservasi hiu dan pengaruhnya terhadap penangkapan hiu adalah sebagai berikut :

a) Formulasi Hipotesis

$H_{0}: \beta_{1} \leq 0$ :persepsi nelayan terhadap status konservasi hiu tidak berpengaruh negatif dan signifikan terhadap penangkapan hiu di kabupaten Badung.

$H_{1}: \beta_{1}>0$ : persepsi nelayan terhadap status konservasi hiu berpengaruh negatif dan signifikan terhadap penangkapan hiu di kabupaten Badung. 
b) Taraf Nyata

Dengan signifikansi $(\alpha) 5 \%$ atau tingkat keyakinan 95\% derajat bebas. Rumus yang digunakan untuk menentukan derajat bebas ditampilkan pada persamaan 11 .

$d f=n-k$

dimana :

$\mathrm{df}=$ derajat bebas, $\mathrm{n}=$ Jumlah seluruh data

, $\mathrm{k}=$ jumlah variabel dalam model.

c) Kriteria Pengujian

$$
\begin{aligned}
& \text { Ho diterima jika } \boldsymbol{t}_{\text {hitung }}<\boldsymbol{t}_{\text {tabel }} \\
& \mathrm{H}_{0} \text { ditolak jika jika } \boldsymbol{t}_{\text {hitung }}>\boldsymbol{t}_{\text {tabel }}
\end{aligned}
$$

Daerah Pengujian Penerimaan dan Penolakan $\mathrm{H}_{0}$ untuk variabel $\mathrm{X}_{1}$ dapat dilihat pada Gambar 2.

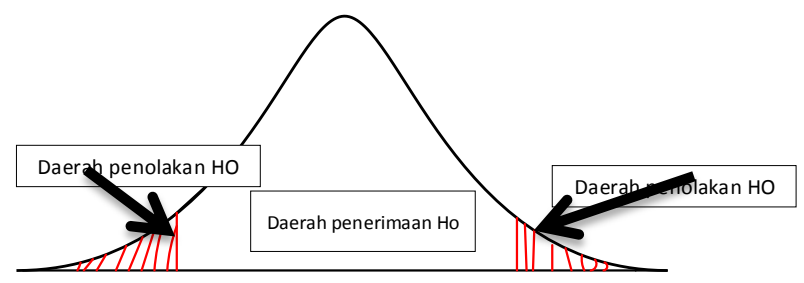

Gambar 2. Daerah Pengujian Penerimaan dan Penolakan $\mathrm{H}_{0}$ untuk variabel $\mathrm{X}_{1}$.

\section{Hasil dan Pembahasan}

\subsection{Karakteristik Responden}

Karakteristik nelayan di kabupaten Badung berdasarkan jenis kelamin menunjukkan bahwa seluruh responden berjenis kelamin laki - laki. Selain itu, karakteristik responden juga dapat dilihat berdasarkan umur dan tingkat pendidikan. Berdasarkan UU nomor 13 Tahun 2003 tentang ketenagakerjaan menyatakan bahwa usia antara 15 - 65 Tahun termasuk dalam kategori tenaga kerja. Hasil penelitian menunjukkan bahwa umur nelayan antara 16 - 67 tahun, dimana yang termasuk dalam kategori tenaga kerja adalah sebesar 98\%. Hal ini menunjukan bahwa nelayan dianggap dapat bekerja dan mampu bekerja untuk memenuhi kebutuhannya.

Karakteristik nelayan berdasarkan tingkat pendidikan dapat dilihat pada Tabel 4. Tingkat pendidikan nelayan di kabupaten Badung menunjukkan bahwa 7,5\% tidak mengenyam pendidikan, 55\% lulusan Sekolah Dasar (SD), 5\% lulusan Sekolah Menengah Pertama (SMP), 31\% lulusan Sekolah Menengah Atas atau sederajat (SMA/SMK), 1\% lulusan Diploma 1 (D1), dan 0,5\% lulusan Diploma 3 (D3). Dengan tingkat pendidikan nelayan yang rendah (Pendidikan dasar dan tidak sekolah) menyebabkan kurangnya pemahaman dan keterampilan tentang makna sumber daya alam di masa mendatang (Hastanti dan Triantoro, 2012).

Tabel 4.

Nelayan di kabupaten Badung berdasarkan tingkat pendidikan.

\begin{tabular}{clcc}
\hline No & $\begin{array}{c}\text { Tingkat } \\
\text { Pendidikan }\end{array}$ & $\begin{array}{c}\text { Jumlah } \\
\text { (Orang) }\end{array}$ & $\begin{array}{c}\text { Persentase } \\
(\%)\end{array}$ \\
\hline 1 & Tidak Sekolah & 15 & 7,5 \\
2 & SD & 111 & 55 \\
3 & SMP & 10 & 5 \\
4 & SMA & 62 & 31 \\
5 & D1 & 2 & 1 \\
6 & D3 & 1 & 0.5 \\
& Jumlah & 201 & 100 \\
\hline
\end{tabular}

\subsection{Persepsi Nelayan Terhadap Status Konservasi Hiu}

Telah dilakukan wawancara terhadap 200 nelayan di kabupaten badung terkait dengan persepsi nelayan terhadap status konservasi hiu. Berdasarkan hasil kuesioner didapatkan bahwa penjualan ikan hiu bukan sebagai sumber pendapatan utama nelayan di kab. Badung, karena penjualan ikan hiu bukan merupakan salah satu pendapatan nelayan dalam memenuhi kebutuhan sehari-hari mereka. Persepsi nelayan terhadap status konservasi hiu juga dapat diketahui berdasarkan pengetahuan nelayan terhadap hiu.

Hasil kuesioner menunjukkan bahwa 75\% nelayan sudah memiliki pengetahuan terkait peran hiu di lautan, dan pemanfaatan hiu. Pengetahuan ini ditunjukkan dengan pernyataan mereka yang setuju bahwa hiu memiliki peranan penting di laut karena merupakan pemangsa tingkat tinggi dalam rantai makanan serta dikenal sebagai pengontrol populasi dan dapat menjaga keseimbangan ekosistem di lautan. Terkait dengan pemanfaatan hiu, nelayan menyatakan bahwa mereka mengetahui pemanfaatan ikan hiu berupa sirip, minyak, dan daging. Jika dilihat dari karakteristik pendidikan nelayan yang didominasi dari kategori pendidikan dasar (SD dan tidak sekolah), pengetahuan nelayan ini tidak berasal dari pendidikan formal melainkan dari pengalaman mereka dilapangan sebagai nelayan. 
Pengetahuan mengenai jenis - jenis hiu yang dilindungi dan dilarang tangkap masih kurang baik. Pengetahuan ini dilihat dari hasil kuesioner dimana nelayan salah memilih jenis hiu yang dilindungi dan dilarang tangkap. Nelayan yang memilih jenis hiu martil, hiu taji, dan hiu mungsing, dimana jenis hiu tersebut tidak dilindungi dan tidak dilarang tangkap sebesar $53 \% ; 12 \%$ nelayan hanya memilih hiu paus; $22 \%$ nelayan memilih hiu paus dan hiu kera/tikus; sedangkan hanya $13 \%$ nelayan memilih jawaban yang paling benar yaitu hiu paus, hiu kera/tikus , hiu putih. Kurangnya pengetahuan nelayan terkait jenis - jenis hiu yang dilindungi dan dilarang tangkap dikarenakan. Kurangnya sosialisasi secara langsung terhadap konservasi hiu dari pemerintah, dimana $87,5 \%$ nelayan mengaku tidak ada sosialisasi dari pemerintah terkait dengan konservasi hiu. Nelayan mengharapkan adanya sosialisasi secara langsung terkait upaya perlindungan hiu baik dari pihak pemerintah maupun lembaga - lembaga lainnya yang bergerak dalam bidang konservasi hiu.

Untuk mendukung kegiatan konservasi diperlukan adanya pengawasan dan penegakkan hukum oleh aparat berwenang kepada pelanggar. Hasil kuesioner menunjukkan bahwa $86 \%$ nelayan menyatakan tidak pernah ada kegiatan pengawasan oleh aparat yang berwenang terhadap penangkapan hiu yang dilindungi. Hal ini menyebabkan terdapat peluang untuk pelaku penangkap hiu yang dilindungi untuk melakukan kegiatannya. Terkait dengan pelaku penangkapan hiu yang dilarang tangkap dan dilindungi, sebanyak 59\% nelayan setuju bahwa mereka harus diberi tindakan tegas atau sanksi, mengingat pengetahuannya tentang pentingnya hiu di laut.

Nelayan merupakan pelaku utama dalam suatu kelompok masyarakat yang berinteraksi langsung dengan lautan dan menjadi faktor penting dalam kegiatan konservasi hiu, serta berpotensi mendorong perubahan dalam setiap kebijakan yang berhubungan dengan kegiatan konservasi. Hal ini sesuai dengan hasil penelitian Winata dan yuliana (2012) tentang peran nelayan dalam upaya penangkapan yang sangat berpengaruh terhadap kegiatan konservasi, dimana penangkapan jenis ikan tertentu (tongkol, tuna, layur) dapat menyebabkan spesies ikan tersebut cepat mengalami kepunahan, jika penangkapannya tidak sesuai dengan potensi lestari (MSY/Maximum Sustainable Yield) . Pandangan atau persepsi nelayan terhadap status konservasi hiu merupakan informasi penting untuk kegiatan konservasi hiu. Persepsi nelayan terhadap status konservasi hiu di kabupaten Badung didasarkan pada 3 komponen penting yaitu pengetahuan, ekonomi, dan penegakkan hukum. Berdasarkan 3 komponen penting tersebut, persepsi nelayan terhadap status konservasi hiu di kabupaten Badung memiliki angka indeks sebesar 0,56 , artinya tergolong baik.

\subsection{Penangkapan Hiu}

Secara umum hiu yang didaratkan di kabupaten Badung merupakan hasil tangkapan sampingan nelayan, namun sebanyak $86 \%$ nelayan mengaku pernah mendapatkan ikan hiu. Ketika mendapatkan ikan hiu, 60\% nelayan menyatakan jika hiu yang tertangkap masih dalam keadaan hidup dan akan dilepaskan kembali ke laut, hal ini didukung dengan pengetahuan mereka mengenai cara melepaskan ikan hiu yang terjaring pada alat tangkap mereka. Hasil kuesioner menunjukkan bahwa $11 \%$ nelayan mengaku pernah mendapatkan bayi hiu (baby shark) yang kemudian akan dijual atau dikonsumsi sendiri.

Terkait dengan jenis hiu yang dilarang tangkap yaitu Alopias spp (Hiu tikus), sebanyak 20\% nelayan mengaku pernah menangkapnya. Alopias spp. merupakan salah satu jenis hiu yang dilarang tangkap di daerah perairan laut lepas Indonesia menurut Peraturan Menteri Kelautan dan Perikanan (Permen KP) Republik Indonesia nomor 12 Tahun 2012. Berdasarkan Permen KP no 12 Tahun 2012 menyatakan bahwa tindakan konservasi yang harus dilakukan pada Hiu tikus adalah dengan melepaskan kembali hiu tersebut jika masih keadaan hidup, jika sudah mati maka harus didaratkan dalam keadaan utuh, kemudian melakukan pencatatan jenis ikan hiu yang tertangkap dan melaporkannya kepada Direktur Jenderal melalui kepala pelabuhan pangkalan. Nelayan yang mengaku akan melepaskan hiu tikus kembali ke laut jika masih hidup adalah sebesar $62 \% \quad(20 \%$ dari seluruh nelayan $)$, sedangkan sisanya ( $48 \%$ nelayan) mengaku akan membawa utuh ke darat tanpa dilaporkan kepada kepala pelabuhan pangkalan, yang kemudian akan dijual.

Nelayan di kabupaten Badung kurang tertarik dengan penangkapan hiu. Hal ini terlihat dari pernyataan $73 \%$ nelayan yang mengaku tidak setuju dengan pernyataan ketika menemukan hiu 
di laut maka mereka akan menangkapnya. Hal ini terkait dengan pengetahuan yang kurang dari nelayan terhadap jenis-jenis hiu dilindungi, sehingga mereka kurang tertarik dengan penangkapan hiu karena nelayan menganggap semua jenis hiu dilindungi. Kurangnya pengetahuan nelayan ini dikarena nelayan hanya mendapat informasi melalui media massa (televisi) dan media cetak (spanduk/banner). Hal ini dirasa nelayan kurang efektif dan komunikatif karena mereka ingin mengetahui informasi yang lebih detail dan adanya diskusi yang lebih interaktif terkait dengan kebijakan-kebijakan tentang konservasi hiu. Secara umum nelayan menyatakan tidak terjadi peningkatan tangkapan hiu di lingkungan mereka. Nelayan juga menyatakan bahwa jarang terjadi penangkapan hiu di lingkungan mereka. Penangkapan hiu berhubungan dengan konservasi di kabupaten Badung memiliki angka indeks sebesar 0,17, artinya tergolong sangat baik.

\subsection{Persepsi Nelayan Terhadap Status Konservasi Hiu dan Pengaruhnya Terhadap Penangkapan Hiu}

Koefisien korelasi atau $\mathrm{R}$ antara persepsi nelayan terhadap status konservasi hiu dengan penangkapan hiu adalah sebesar $-0,62$ sehingga memiliki hubungan negatif yang kuat. Berdasarkan hasil tersebut ketika persepsi nelayan terhadap status konservasi hiu di kabupaten Badung meningkat maka penangkapan hiu di kabupaten Badung akan menurun. Koefisien determinasi atau $\mathrm{R}^{2}$ adalah sebesar 0,38,4. Hal ini berarti nilai rata-rata penangkapan hiu di kabupaten Badung 38,4\% ditentukan oleh persepsi nelayan terhadap status konservasi hiu di kabupaten Badung, melalui persamaan regresi $\mathrm{Y}=$ $33.378192-0.515803 X$.

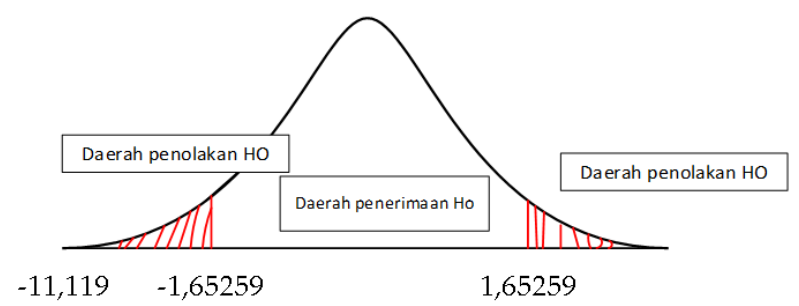

Gambar 3. Daerah Hasil Pegujian Penerimaan dan Penolakan H0 untuk Variabel X.

Dengan signifikansi $(\alpha) \quad 5 \%$ atau tingkat keyakinan 95 persen didapatkan $t$ hitung $(-11,119)>t$ tabel $(-1,65259)$, namun jika dilihat dari daerah hasil pengujian penerimaan dan penolakkan $\mathrm{H}_{0}$ untuk variabel $\mathrm{X}$, maka $\mathrm{H}_{0}$ ditolak yang berarti persepsi nelayan terhadap status konservasi hiu berpengaruh terhadap penangkapan hiu di kabupaten Badung (Gambar 3).

\section{Simpulan}

Persepsi nelayan terhadap status konservasi hiu di kabupaten Badung tergolong dalam kualifikasi baik, sedangkan penangkapan hiu di kabupaten Badung berhubungan dengan konservasi hiu tergolong sangat baik. Koefisien korelasi atau $\mathrm{R}$ antara persepsi nelayan terhadap status konservasi hiu dengan penangkapan hiu memiliki hubungan negatif yang kuat, hal ini berarti ketika persepsi nelayan terhadap status konservasi hiu di kabupaten Badung meningkat maka penangkapan hiu di kabupaten Badung akan menurun. Penangkapan hiu di kabupaten Badung 38,4\% ditentukan oleh persepsi nelayan terhadap status konservasi hiu di kabupaten Badung.

\section{Ucapan Terima Kasih}

Penulis mengucapkan terimakasih kepada penguji yang telah memberikan saran dan masukan dan Lab komputasi yang telah memfasilitasi saya dalam menyelesaikan penelitian. Penulis mengucapkan terima kasih kepada Dinas Peternakan, Kelautan dan Perikanan yang telah menyediakan data terkait dengan penelitian ini. Penulis mengucapkan terimakasih kepada reviewer yang telah memberikan saran dan masukan. Penulis juga mengucapkan terimakasih kepada Maria Ulfa, Iyan Sihombing, Yuli, dan Bintang Gustavina yang telah membantu pengambilan sampel, serta rekan-rekan mahasiswa Ilmu Kelautan Angkatan II Universitas Udayana.

\section{Daftar Pustaka}

Bangun, O. V. \& Pahlawan, I. (2014). Efektivitas cites (Convention on international trade in endangered spesies of wild fauna and flora) dalam mengatur perdagangan Hiu di kawasan coral triangle (Implementasi Di Indonesia). Jurnal Jom FISIP, 1(2), 112.

Boone, H. N. \& Boone, D. A. (2012). Analyzing likert data. Journal of extension, 50(2), 1-5.

Fachry, M. E. \& Pertamasari, A. (2011). Analisis efektifitas metode penyuluhan pada masyarakat 
pesisir di Kabupaten Pangkep Sulawesi Selatan. Jurnal Agribisnis, 10(3), 69-80.

Ferdiansyah, D. \& Hidayat, M. T. (2017). Ancaman perikanan skala kecil terhadap hiu di Sumenep untuk kebutuhan pengelolaan yang efektif dan berkelanjutan. Jurnal Agrosains: Karya Kreatif Dan Inovatif, 3(1), 224-232

Handayani, N. M. P., Julyantoro, P. G. S., \& Negara, I. K. W. (2018). Alur Perdagangan Hiu sebagai Komoditas Ikan Hias dari Provinsi Bali. Journal of Marine and Aquatic Sciences, 4(1), 58-66.

Hastanti, B. W. \& Triantoro, R. G. N. (2012). Kondisi sosial ekonomi dan budaya masyarakat sekitar kawasan konservasi: studi kasus di Pulau Gag, Raja Ampat, Papua Barat. Jurnal Penelitian Kehutanan Wallacea, 1(2), 149-164.

Hendra, N., Sangadji, M. I. \& Yudiarsa, P. (2016). Komposisi Spesies, Distribusi panjang dan Rasio kelamin Ikan yang Didaratkan di Jawa Timur, Bali, NTB dan NTT. Dalam Prosiding Simposium Hiu dan Pari di Indonesia: Biologi, Populasi, Ekologi, Sosial-Ekonomi, Pengelolaan dan Konservasi. Bogor, Indonesia, 10 Juni 2015 (pp. 31-41).

Jabado, R. W., Al Ghais, S. M., Hamza, W., Henderson, A. C., Spaet, J. L., Shivji, M. S. \& Hanner, R. H. (2015). The trade in sharks and their products in the United Arab Emirates. Biological Conservation, 181, 190-198.

Jansen, H. (2010). The logic of qualitative survey research and its position in the field of social research methods. Forum Qualitative Sozialforschung/Forum: Qualitative Social Research, 11(2), 1-21.

Rahmat, E. (2011). Teknik pengukuran morfometrik pada ikan cucut di perairan Samudera Hindia. Buletin Teknik Litkayasa (BTL), 9(2), 1-9.

Republik Indonesia. (2003). Undang - Undang Republik Indonesia Nomor 13 Tahun 2003 tentang Ketenagakerjaan. Jakarta-Indonesia: Sekretaris Negara Republik Indonesia.

KKP. (2012). Peraturan Menteri Kelautan dan Perikanan Nomor 12 Tahun 2012 tentang Usaha Perikanan Tangkap di Laut Lepas. Jakarta-Indonesia: Kementerian Kelautan dan Perikanan Republik Indonesia.
Retnowati, E. (2011). Nelayan Indonesia dalam pusaran kemiskinan struktural (perspektif sosial, ekonomi dan hukum). Perspektif, 16(3), 149-159.

Saraswati, W. K., Susiatiningsih, H. \& Farabi, N. (2016). Respon pemerintah Indonesia terkait sekuritisasi WWF melalui kampanye save our sharks. Journal of International Relations, 2(4), 68-77.

Sembiring, A., Pertiwi, N. P. D., Mahardini, A., Wulandari, R., Kurniasih, E. M., Kuncoro, A. W., Cahyani, N. K. D., Anggoro, A. W., Ulfa, M., Madduppa, H. H., Carpenter, K. E., Barber, P. H. \& Mahardika, G. N. (2015). DNA barcoding reveals targeted fisheries for endangered sharks in Indonesia. Fisheries Research, 164, 130-134.

Setyadji, B., Nugraha, B. \& Jatmiko, I. (2014). Commonly discarded fishes on Indonesian tuna longline fishery in Indian Ocean. In IOTC 9th Working Party on Ecosystems and Bycatch (WPEB). La Réunion, France, 12-16 September 2013 (IOTC-2013-WPEB09-33).

Simpfendorfer, C. A., Heupel, M. R., White, W. T. \& Dulvy, N. K. (2011). The importance of research and public opinion to conservation management of sharks and rays: a synthesis. Marine and Freshwater Research, 62(6), 518-527.

Sugiyono. (2016). Metode Penelitian Kuantitatif Kualitatif dan RED. Bandung, Indonesia: Alfabeta.

Suryagalih, S. (2016). Studi pengelolaan perikanan hiu di pantai utara Pulau Jawa. Marine Fisheries: Journal of Marine Fisheries Technology and Management, 3(2), 149159.

Winata, A. \& Yuliana, E. (2012). Peran masyarakat pesisir dalam penerapan strategi konservasi sumberdaya laut (Kasus di Kelurahan Palabuhanratu, Kecamatan Palabuhanratu, Kabupaten Sukabumi). Jurnal Matematika, Sains, Dan Teknologi, 11(2), 122-132.

Worm, B., Davis, B., Kettemer, L., Ward-Paige, C. A., Chapman, D., Heithaus, M. R., Kessel, T. S. \& Gruber, S. H. (2013). Global catches, exploitation rates, and rebuilding options for sharks. Marine Policy, 40, 194204.

(C) 2017 by the authors; licensee Udayana University, Indonesia. This article is an open access article distributed under the terms and conditions of the Creative Commons Attribution license (http://creativecommons.org/licenses/by/3.0/). 